\title{
The concept of time in the perception of children and adolescents
}

\author{
O conceito de tempo na percepção de crianças e adolescentes
}

\author{
Fernando Michel, ${ }^{1}$ Francine Harb, ${ }^{1}$ Maria Paz Loayza Hidalgo ${ }^{2}$
}

\begin{abstract}
Introduction: Children and adolescents use different markers to elaborate the concept of time, and such markers change along their development. The objective of the present article was to analyze changes in time concepts in different age groups.

Methods: The study included 81 children and adolescents aged 6 to 17 years, attending elementary or high school at a public school in southern Brazil. Participants were asked to provide their definition of time, either orally (children) or in writing (older children and adolescents).

Results: Twenty-one words were identified as related with the definition of time. The term "hours" was the most frequently cited (24.7\%), followed by "clock" and "family" (11.1\% each). Among children aged 6 to 8 years, "family" was the term most frequently mentioned to refer to time. Between 9 to 11 years of age, the notion of time was essentially related to the use of a clock, and in the 12-17-year age group, time was mostly associated with the word "days." The word "family" appears to be a frequent temporal marker in childhood, but loses this function during adolescence, as new social relationships are established. Conclusion: The results of this study show that the concept of time varies according to age. Chronobiological studies should therefore take into consideration the temporal perception peculiar to each age group.
\end{abstract}

Keywords: Chronobiology, biological rhythm, human development, learning, education.

\section{Resumo}

Introdução: Crianças e adolescentes utilizam diferentes marcadores para a construção do conceito de tempo, os quais se modificam ao longo do desenvolvimento. $\mathrm{O}$ objetivo deste artigo foi analisar mudanças em conceitos temporais e suas transições ao longo da idade.

Material e métodos: Participaram do estudo 81 crianças e adolescentes com idade entre 6 e 17 anos, estudantes do ensino médio e fundamental de uma escola pública do sul do Brasil. Solicitou-se aos participantes que informassem sua definição de tempo, verbalmente (crianças) ou por escrito (crianças mais veIhas e adolescentes).

Resultados: Foram identificadas 21 palavras relacionadas com a definição de tempo. O termo "horas" foi o mais citado $(24,7 \%)$, seguido de "relógio" e "família" (11,1\% cada). Entre 6 e 8 anos, o termo "família" foi o mais frequentemente mencionado para se referir ao tempo. Entre 9 e 11 anos, a noção de tempo esteve relacionada ao uso do relógio, e entre 12 e 17 anos, o tempo foi associado principalmente à palavra "dias". Na infância, o termo "família" é um marcador temporal recorrente, mas perde tal significado na adolescência, à medida que surgem novas relações sociais.

Conclusão: Os resultados deste estudo mostraram que o conceito de tempo varia conforme a idade. Portanto, estudos cronobiológicos devem considerar a percepção temporal própria para cada faixa etária.

Descritores: Cronobiologia, ritmo biológico, desenvolvimento humano, aprendizagem, educação.

\footnotetext{
${ }^{1}$ Laboratório de Cronobiologia, Hospital de Clínicas de Porto Alegre (HCPA), Universidade Federal do Rio Grande do Sul (UFRGS), Porto Alegre, RS, Brazil. ${ }^{2}$ Laboratório de Cronobiologia, HCPA, UFRGS. Departamento de Psiquiatria e Medicina Legal, Faculdade de Medicina, UFRGS. Programa de Pós-Graduação em Psiquiatria, Faculdade de Medicina, UFRGS.

Submitted May 25 2011, accepted for publication Aug 31 2011. No conflicts of interest declared concerning the publication of this article.

Suggested citation: Michel F, Harb F, Hidalgo MP. The concept of time in the perception of children and adolescents. Trends Psychiatry Psychother. 2012;34(1):38-41.
} 


\section{Introduction}

The notion of current time, both individually and socially, qualifies and distinguishes human beings from other species; humans use time as a reference for their social activities and for constructing their history. ${ }^{1}$ Time serves essentially as a means of orientation in the social universe and as a regulator of social coexistence. ${ }^{2}$

Discussions on the perception of time are not limited to one single culture or science. Several fields of knowledge have contributed toward a better understanding and a broader discussion on the topic. Some of the fields that deserve mention include: physics, with the Newtonian gravitation theory and the Einstein theory of relativity; mathematics, from the perspective of validation when time is seen as movement and quantification; psychology, with studies focusing on temporal disorders; social sciences, dwelling on concepts of social and cultural time; and biology, especially with chronobiological studies, which assess the importance of time for living organisms.

By observing certain constant and cyclic biological phenomena, chronobiology divides time according to biological rhythms, describing and quantifying such rhythms. Biological rhythms can be defined as regular variations in biological parameters and changes associated with development. ${ }^{3}$

In modern society, time has been standardized as a linear progression measured by the clock and the calendar, in a way that dominates our daily living. However, in primitive cultures and ancient civilizations, time was measured according to cyclic natural phenomena. Time expresses the rhythm of collective activities, but also indirectly regulates such activities. ${ }^{2}$ The social nature of time ends up working as a set of relationships that establish an order and a rhythmic pattern for social events. For example, several studies have shown the relationship between preferred timing of sleep and psychological well-being, learning, and psychiatric/psychosomatic disorders. ${ }^{4,6}$

The perception of time is closely associated with external changes; as a result, time intervals affected by fewer changes are perceived as less intense than intervals in which a higher number of changes take place. In the case of children, the perception of time is strongly associated with their own development, forcing them to deal with cultural, social, and personal timeframes. Although cultural timing tends to be firmly established in the lives of children, they often show the desire to be always on the right time (an essential factor for improving their concept of time). ${ }^{6}$
The objective of this study was to assess the perception of time among children and adolescents, with a focus on changes in time concepts in different age groups.

\section{Method}

\section{Participants}

This quantitative and exploratory study was approved by the Research Ethics Committee of Hospital de Clínicas de Porto Alegre (protocol no. 10-0128).

A total of 81 participants, including children and adolescents (51.9\% females), aged 6 to 17 years, took part in the study. All participants were attending elementary or high school at a public school in the municipality of Gravataí, southern Brazil. Data were collected in February 2011 in 10 groups of volunteers, asking only one question with the objective of comparing the answers of children and adolescents to the same question. The study was conducted in accordance with applicable ethical guidelines, especially regarding interviewee anonymity. All answers were reproduced in full, which made it possible to analyze the perception of time elicited by interviewees of different ages and educational levels.

\section{Instruments}

A questionnaire comprising only one question ("What is time?") was applied. Among children aged 6 to 8 years, answers were obtained orally during an interview; patients aged 9 to 17 years were given a piece of paper containing the question and were advised to answer it without the help of other people, using only their own understanding and knowledge on the topic. All participants were also asked to provide more than one response, if possible, and to present the different answers in a hierarchical order (first, second, third, and fourth options).

\section{Data analysis}

Data were analyzed and results expressed as frequencies according to age groups. Analyses were performed using the Statistical Package for the Social Sciences (SPSS) version 18.0.

\section{Results}

A total of 21 words were identified as related to the participants' main concepts of time. The term most frequently cited was "hours" (24.7\%), followed by "clock" 
Table 1 - Most frequently cited words according to age, n (\%)

\begin{tabular}{|c|c|c|c|}
\hline Words associated with the concept of time & $6-8$ years $(n=20)$ & $9-12$ years $(n=15)$ & $13-17$ years $(n=46)$ \\
\hline \multicolumn{4}{|l|}{ First option } \\
\hline Family & $8(40)$ & $1(6.7)$ & 0 \\
\hline Weather & $2(10)$ & $3(20)$ & $2(4.3)$ \\
\hline Soccer & $2(10)$ & 0 & $2(4.3)$ \\
\hline Play & $2(10)$ & 0 & $1(2.2)$ \\
\hline Hours & $1(5)$ & $3(20)$ & $16(34.8)$ \\
\hline Past & $1(5)$ & $2(13.3)$ & $2(4.3)$ \\
\hline Friends & $1(5)$ & $1(6.7)$ & $1(2.2)$ \\
\hline Year & $1(5)$ & 0 & 0 \\
\hline Computer & $1(5)$ & 0 & 0 \\
\hline Week & $1(5)$ & 0 & 0 \\
\hline Invisible & 0 & $2(13.3)$ & $1(2.2)$ \\
\hline Clock & 0 & $1(6.7)$ & $8(17.4)$ \\
\hline Day & 0 & $1(6.7)$ & $1(2.2)$ \\
\hline Pain & 0 & $1(6.7)$ & $1(2.2)$ \\
\hline Wait & 0 & 0 & $3(6.5)$ \\
\hline Speed & 0 & 0 & $3(6.5)$ \\
\hline Happiness & 0 & 0 & $2(4.3)$ \\
\hline Drive & 0 & 0 & $1(2.2)$ \\
\hline Space & 0 & 0 & $1(2.2)$ \\
\hline Experience & 0 & 0 & $1(2.2)$ \\
\hline \multicolumn{4}{|l|}{ Second option } \\
\hline Computer & $1(5)$ & 0 & $1(2.2)$ \\
\hline Change, cycle & $1(5)$ & 0 & 0 \\
\hline Days & 0 & $2(13.3)$ & $7(15.2)$ \\
\hline Weather & 0 & $1(6.7)$ & $3(6.5)$ \\
\hline Future & 0 & $1(6.7)$ & $1(2.2)$ \\
\hline Friends & 0 & $1(6.7)$ & 0 \\
\hline Abstract & 0 & 0 & $1(2.2)$ \\
\hline Happiness & 0 & 0 & $1(2.2)$ \\
\hline Months & 0 & 0 & $1(2.2)$ \\
\hline \multicolumn{4}{|l|}{ Third option } \\
\hline Sleep & $1(5)$ & 0 & 0 \\
\hline Study & 0 & $1(6.7)$ & 0 \\
\hline Past & 0 & $1(6.7)$ & 0 \\
\hline Months & 0 & 0 & $4(8.7)$ \\
\hline Weather & 0 & 0 & $2(4.3)$ \\
\hline Happiness & 0 & 0 & $1(2.2)$ \\
\hline Hygiene & 0 & 0 & $1(2.2)$ \\
\hline \multicolumn{4}{|l|}{ Fourth option } \\
\hline Pain & 0 & 0 & $1(2.2)$ \\
\hline Years & 0 & 0 & $1(2.2)$ \\
\hline Weather & 0 & 0 & $1(2.2)$ \\
\hline
\end{tabular}

Percentages (in parentheses) refer to the frequency each word is mentioned in the corresponding age group.

and "family" (11.1\% each) (Table 1$)$. Considering all interviewees, $66.7 \%$ presented more than one answer to the question.

When analyzing the words most frequently cited according to age, we observed that the word "family" was the most frequently cited in the 6-8-year age group $(40 \%)$, followed by "play" (Table 1 ). In the 9-11-year age group, the concept of time was frequently related with the use of a clock, with words like "cycle," "days," and "future." Finally, among adolescents aged 12 to 17 years, the association between time and the words "hour" and "clock" in first-option answers was very strong; the association with "days" in second-option answers was also evident, accounting for $15.2 \%$ of these answers (Table 1 ).

\section{Discussion}

The results of the present study showed that the concept of time changes as age increases, as observed in the comparison between children and adolescents. In young children (6-8 years), the concept of time is closely related with family and leisure time (play). For Vygotsky \& Luria, children' play is the origin of social activity, a crucial element for their cultural development, through which they can understand the world. ${ }^{7}$ As the child develops, the term "family" loses its place as the word most closely related with the concept of time and is replaced with others that show a higher influence of external temporal markers. Among 12-17-year old adolescents, time is defined with words such as "hour" 
and "clock," which show these adolescents' concern with the daily routine. These findings also suggest a change in the concept of time, once their adaptation to social relationships is accompanied by regular activities on fixed schedules.

In chronobiology, biological time is strongly associated with external rhythms and with temporal markers called Zeitgebers (from the German for time giver). Zeitgebers can be environmental (e.g. light) or social (e.g. family coexistence), and they frame the biological rhythm so that the body can adapt to external changes and meet social requirements. Social markers define the timing of different habits in a society, and they compete with natural markers - especially the light/dark cycle - when synchronizing biological rhythms. ${ }^{8}$

The need for synchronization increases as the child develops and as their activities increasingly interact with social rhythms. The sequential adaptation to Zeitgebers among children has been clearly shown in our results, once the concept of time changed as a result of different external markers regulating each age group. The clearest example of Zeitgeber adaptation was the reference made to "clock," which is merely a convention used to determine and control social rhythm. ${ }^{8}$

In sum, temporal markers change with age. Therefore, any instruments or studies aimed at measuring social rhythm should take into consideration the temporal perception peculiar to each age group.

\section{References}

1. Ferreira VMR, Arco-Verde YFS. Chrónos \& Kairós: o tempo nos tempos da escola. Educ Rev. 2001;17:63-78.

2. Damasceno AVC. Na medida certa. Anais do I Encontro Regional das Sociedades; 2005; Belém, PA, Brasil.

3. Noguera DA, Riu TC, Hortensi VJ, Cucurella CN. Cronobiologia. Porto Alegre: Livre; 2007

4. Hidalgo MP, Caumo W, Posser M, Coccaro SB, Camozzato AL, Chaves ML. Relationship between depressive mood and chronotype in healthy subjects. Psychiatry Clin Neurosci. 2009;63:283-90.

5. Schneider MLDM, Vasconcellos DC, Dantas G, Levandovski $\mathrm{R}$, Caumo W, Allebrandt $\mathrm{K}$, et al. Morningness-eveningness, use of stimulants, and minor psychiatric disorders among undergraduate students. Int J Psychol. 2010;46:18-23.

6. Hviid P. Dimensões de tempo segundo a percepção de crianças de seu próprio desenvolvimento. Rev Bras Crescimento Desenvolv Hum. 2006;16:69-76.

7. Vygotsky LS, Luria AR. Estudos sobre a história do comportamento: símios, homem primitivo e criança. Porto Alegre: Artes Médicas; 1996.

8. Schimitt RL, Hidalgo MPL, Caumo W. Ritmo social e suas formas de mensuração: uma perspectiva histórica. Estud Pesq Psicol. 2010;2:457-70.

\section{Correspondence:}

Maria Paz Loayza Hidalgo

Núcleo de Cronobiologia, Hospital de Clínicas de Porto Alegre Rua Ramiro Barcelos, 2350, $2^{\circ}$ andar, sala 2201E

90035-903 - Porto Alegre, RS - Brazil

E-mail: mpaz@cpovo.net 